\title{
Synthesis of Substituted Imidazolidin-2-ones as Aminoacyl-tRNA Synthase Inhibitors ${ }^{\dagger}$
}

\author{
Heesung Eum, ${ }^{a}$ Yuno Lee,,${ }^{\ddagger}$ Songmi Kim, ${ }^{\ddagger}$ Ayoung Baek, ${ }^{\ddagger}$ Minky Son, ${ }^{\ddagger}$ Keun Woo Lee, ${ }^{\ddagger}$ \\ Seung Whan Ko, ${ }^{\S}$ Sunghoon Kim, ${ }^{\sharp}$ Sae Young Yun, ${ }^{\mathrm{P}}$ Won Koo Lee, ${ }^{\mathrm{P}, *}$ and Hyun-Joon Ha* \\ Department of Chemistry and Protein Research Center for Bio-Industry, Hankuk University of Foreign Studies, \\ Yongin 449-791, Korea. ${ }^{*}$ E-mail: hjha@hufs.ac.kr \\ ${ }^{\ddagger}$ Division of Applied Life Science (BK21 Program), Environmental Biotechnology National Core Research Center \\ (EB-NCRC), Plant Molecular Biology and Biotechnology Research Center (PMBBRC), \\ Gyeongsang National University (GNU), Jinju 660-701, Korea \\ ${ }^{\S}$ Imagene Co. Ltd., 13th Gyeonggi Bio-Center BD, Suwon 443-270, Korea \\ ${ }^{\#}$ Center for Medicinal Protein Network and Systems Biology, College of Pharmacy, Seoul National University, \\ Seoul 151-741, Korea \\ ${ }^{\mathbb{P}}$ Department of Chemistry, Sogang University, Seoul121-742, Korea. ${ }^{*}$ E-mail: wonkoo@sogang.ac.kr \\ Received December 28, 2009, Accepted January 30, 2010
}

\begin{abstract}
Substituted imidazolidin-2-ones deduced as potential inhibitors of IleRS by docking simulations were synthesized from an aziridine-2-carboxaldehyde. Reductive amination of an aziridine-2-carboxaldehyde with dipeptides for the substituents at N1 and followed by aziridine-ring expansion with triphosgene afforded 4-chloromethylimidazolidin-2-ones whose chloride were further manipulated towards phenylurea, pyrimidin-2-yl-urea or benzenesulfonamide at C4.
\end{abstract}

Key Words: Aminoacyl-tRNA synthase inhibitors, Imidazolidin-2-ones

\section{Introduction}

Aminoacyl-tRNA synthetases (aaRS), an enzyme responsible for the protein biosynthesis for all organisms, are interesting antibacterial drug target. ${ }^{1}$ One commercial antibiotic named mupirocin is a natural product isolated from Pseudomonas fluorescens which inhibits bacterial aaRS (Figure 1). ${ }^{2}$ More specifically it is a bifunctional inhibitor of IleRS with respect to both isoleucine and ATP binding. ${ }^{3}$ Whole chemical structure of mupirocin is quite different from the isoleucyl-adenylate reaction intermediate (Ile-AMP) except the isoleucyl moiety in the tail part. However, both mupirocin and the reactive intermediate bind in very similar regions within the enzyme. ${ }^{4}$ Many compounds for the potential inhibitor were devised on the basis of the structural knowledge binding the enzyme to the inhibitors.

In our early publication ${ }^{5}$ we performed docking simulations with 48 different compounds and some of them showed good binding capabilities for IleRS (S. aureus). They have imidazolidin-2-one as a common core heterocycle with a substituent of dipeptide at N1 and phenylurea (1), pyrimidin-2-yl-urea (2) or benzenesulfonamide (3) at C4. Dipeptide consists with substituents in R1 and R2 originated from either leucine (L) isoleucine (I) (Figure 2). All of these were synthesized and evaluated as IleRS (E.coli and S.aureus) inhibitors.

\section{Results and Discussion}

Synthesis starts from reductive amination of an aziridine-2carboxaldehyde (4) ${ }^{6}$ and amine part of dipeptide methylester (5) to yield 6 . The following aziridine-ring expansion afforded 4chloromethylimidazolidin-2-one (7) with triphosgene in the presence of $\mathrm{NaH}^{7}{ }^{7}$ Removal of phenylethyl group ${ }^{8}$ and the change of chlorine to amine via azide gave common synthetic intermediate 9 , which was further reacted with phenylisocyanate ${ }^{9}$, pyrimidin-2-yl-carbamate ${ }^{10}$ and benzene sulfonyl chloride to afford 10,11 and 12 respectively. Target molecules bearing imidazolidin-2-one as a core heterocycle with a substituent of dipeptide at $\mathrm{N} 1$ and with one of three groups among phenylurea (1), pyrimidin-2-yl-urea (2) or benzenesulfonamide (3) at C4. were attained from hydrolysis of the corresponding methyl

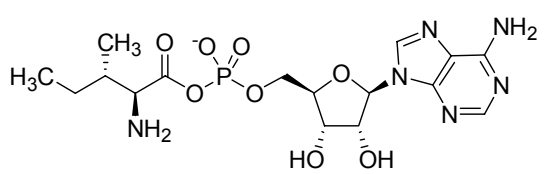

isoleucyl-AMP (Ile-AMP)

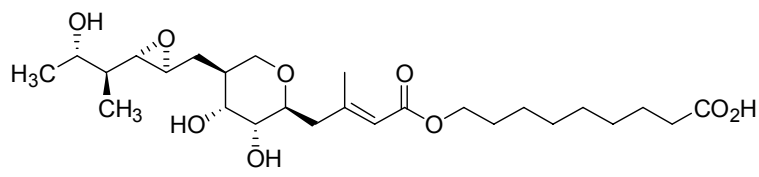

mupirocin

Figure 1. Chemical structures of isoleucyl-AMP (Ile-AMP) and mupirocin.

\footnotetext{
${ }^{\dagger}$ This paper is dedicated to Professor Sunggak Kim on the occasion of his honorable retirement.

${ }^{a}$ These authors have contributed equally to this work.
} 
esters 10, 11 and 12 respectively.

All of the synthesized compounds were evaluated as IleRS (E.coli and S.aureus) inhibitors with two different concentration as 200 and $20 \mu \mathrm{M}$ respectively. ${ }^{11}$ Unfortunately, none of the synthesized compounds showed quite significant inhibitory activity against both IleRS. At this moment we were not able to explain the big discrepancy between the molecular docking study and real inhibitory activity.

In conclusion, we synthesized compounds bearing imidazolidin-2-one as a core heterocycle with a substituent of dipeptide at $\mathrm{N} 1$ and with one of three groups among phenylurea (1), pyrimidin-2-yl-urea (2) or benzenesulfonamide (3) at C4.

\section{Experimental}

Chiral aziridines are available from Aldrich. All commercially available compounds were used as received unless stated otherwise. All reactions were carried out under an atmosphere of nitrogen in oven-dried glassware with magnetic stirring. Reactions were monitored by thin layer chromatography (TLC) with $0.25 \mathrm{~mm}$ E. Merck pre-coated silica gel plates (60 F254). Visualization was accomplished with either UV light, or by immersion in solutions of ninhydrin, $p$-anisaldehyde, or phosphomolybdic acid (PMA) followed by heating on a hot plate for about $10 \mathrm{sec}$. Purification of the reaction products was carried out by flash chromatography using Kieselgel 60 Art 9385 (230 400 mesh). ${ }^{1} \mathrm{H}-\mathrm{NMR}$ and ${ }^{13} \mathrm{C}-\mathrm{NMR}$ spectra were obtained using a Varian 400 (400 MHz for ${ }^{1} \mathrm{H}$, and $100 \mathrm{MHz}$ for $\left.{ }^{13} \mathrm{C}\right)$ spectrometer. Chemical shifts are reported relative to chloroform $(\delta=$ 7.26) for ${ }^{1} \mathrm{H}$ NMR and chloroform $(\delta=77.2)$ for ${ }^{13} \mathrm{C} \mathrm{NMR}$. Data are reported as $(\mathrm{br}=$ broad, $\mathrm{s}=$ singlet, $\mathrm{d}=$ doublet, $\mathrm{t}=$ triplet, $\mathrm{q}=$ quartet, $\mathrm{m}=$ multiplet.) Coupling constants are given in $\mathrm{Hz}$. High resolution mass spectra were recorded on a 4.7 Tesla IonSpec ESI-FTMS or a Micromass LCT ESI-TOF mass spectrometer.

Preparation of amino acid dimers (LL, LI, II and IL). To the solution of Boc-leucine ( $3 \mathrm{~g}, 13 \mathrm{mmol}$ ) in $20 \mathrm{~mL}$ of EtOAc under nitrogen at room temperature was added 4-methylmorpholine $(1.5,13.7 \mathrm{mmol})$, HOBt $(0.18 \mathrm{~g}, 1.3 \mathrm{mmol})$. To the above mixture were added leucine methyl ester (2.36 g, 13 $\mathrm{mmol})$, DCC (3.2 g, $14.6 \mathrm{mmol})$ in $3 \mathrm{~mL}$ EtOAc. The mixture was stirred for 2 hours at room temperature. The resulting urea was removed by filtration. The mixture was treated with water, and the aqueous layer was separated and extracted with EtOAc. The combined organic extracts were washed with $5 \% \mathrm{~K}_{2} \mathrm{CO}_{3}$, $5 \% \mathrm{KHSO}_{4}$, and brine. The organic layer was dried over anhydrous $\mathrm{MgSO}_{4}$, filtered, and concentrated in vacuo. Residue was recystallization from pet ether to provide $92 \%$ of $N$-Boc

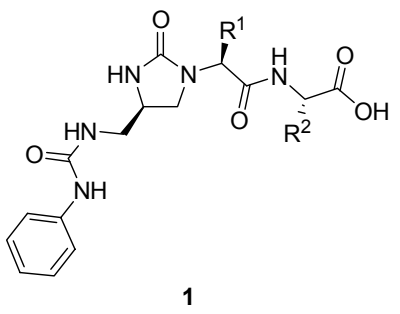

1LL $\mathrm{R}^{1}=$ iso-Butyl, $\mathrm{R}^{2}=$ iso-Butyl

1LI $\mathrm{R}^{1}=$ iso-Butyl, $\mathrm{R}^{2}=$ sec-Butyl

1II $\mathrm{R}^{1}=$ sec-Butyl, $\mathrm{R}^{2}=$ sec-Butyl

1IL $\mathrm{R}^{1}=$ sec-Butyl, $\mathrm{R}^{2}=$ iso-Butyl

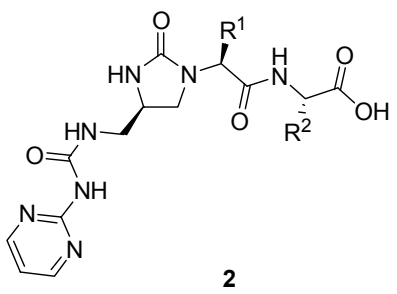

2LL $\mathrm{R}^{1}=$ iso-Butyl, $\mathrm{R}^{2}=$ iso-Butyl

2LI $\mathrm{R}^{1}=$ iso-Butyl, $\mathrm{R}^{2}=$ sec-Butyl

2II $\mathrm{R}^{1}=$ sec-Butyl, $\mathrm{R}^{2}=$ sec-Butyl

2IL $\mathrm{R}^{1}=$ sec-Butyl, $\mathrm{R}^{2}=$ iso-Butyl

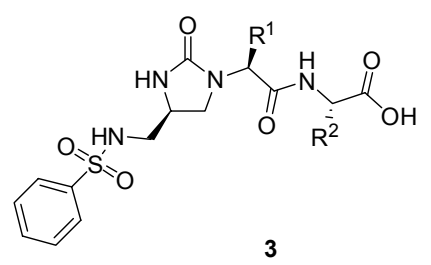

3LL $\mathrm{R}^{1}=$ iso-Butyl, $\mathrm{R}^{2}=$ iso-Butyl

3LI $\mathrm{R}^{1}=$ iso-Butyl, $\mathrm{R}^{2}=$ sec-Butyl

3II $\mathrm{R}^{1}=$ sec-Butyl, $\mathrm{R}^{2}=$ sec-Butyl

3IL $\mathrm{R}^{1}=$ sec-Butyl, $\mathrm{R}^{2}=$ iso-Butyl

Figure 2. Chemical structures of potential inhibitors of IleRS based on docking simulations.
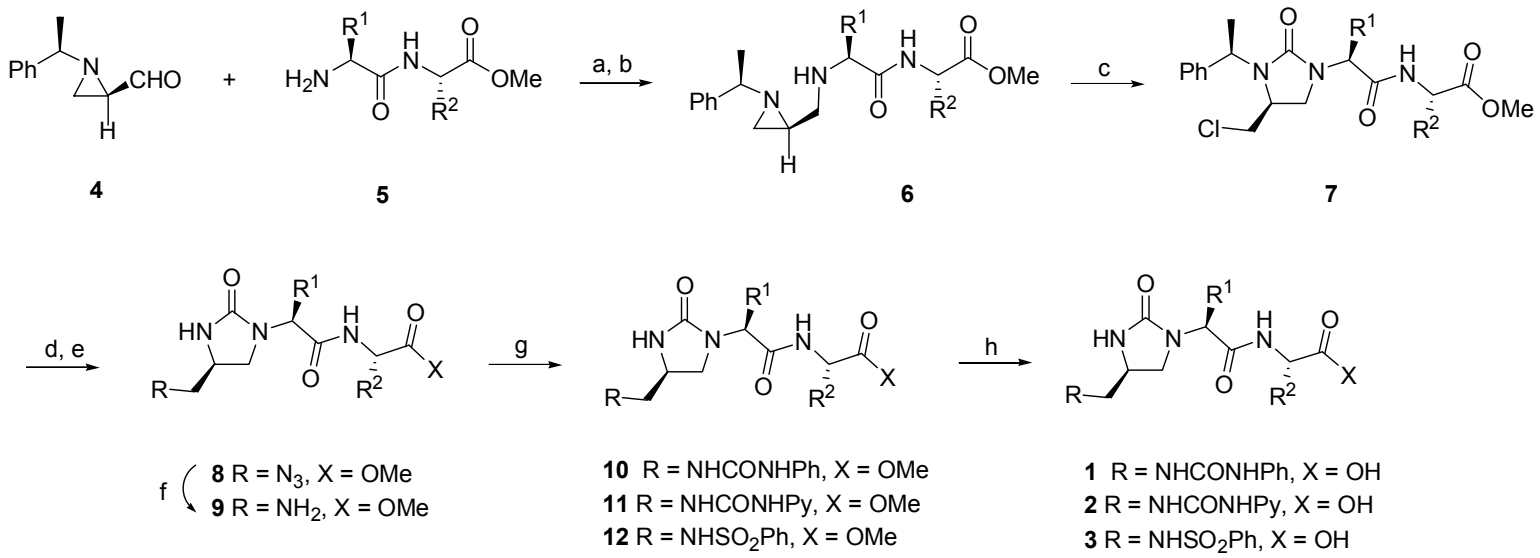

${ }^{*} \mathrm{R}^{1}$ and $\mathrm{R}^{2}$ represent either iso-Butyl and(or) sec-Butyl. All compounds represent one of four possibilities combination between iso-Butyl and(or) sec-Butyl.

Scheme 1. (a) $\mathrm{MgSO}_{4}$; (b) $\mathrm{NaCNBH}_{3}$; (c) Triphosgen, $\mathrm{NaH}$; (d) $\mathrm{CH}_{3} \mathrm{SO}_{3} \mathrm{H}$, anisole; (e) $\mathrm{NaN}_{3}$; (f) $\mathrm{H}_{2}, \mathrm{Pd} / \mathrm{C}$; (g) $\mathrm{PhNCO}$ (for 10); $\mathrm{PyNHCO} 2 \mathrm{Ph}$ (for 11); $\mathrm{PhSO}_{2} \mathrm{Cl}$ (for 12); (h) $1 \mathrm{~N} \mathrm{NaOH}$. 
protected leucine-leucine (LL) dimer. After mixture was treated with $4 \mathrm{~N} \mathrm{HCl}$ in dioxane, Boc deprotected leucine-leucine (LL) dimer methyl ester was obtained which is ready to be coupled with aldehyde. All other three dimers including leucine-isoeucine (LI), isoleucine-isoeucine (II) and isoleucine-leucine (IL) methyl ester were prepared in the same manner starting from the corresponding amino acids.

Preparation of 6. To the solution of deprotected leucine-leucine (LL) dimer methyl ester $(2.6 \mathrm{~g}, 10.2 \mathrm{mmol})$ in $70 \mathrm{~mL}$ of $\mathrm{CH}_{2} \mathrm{Cl}_{2}$ under nitrogen at room temperature were added aziridine aldehyde (1.78 g, $10.2 \mathrm{mmol})$ and anhydrous $\mathrm{MgSO}_{4}(10$ $\mathrm{g})$. The solution was stirred for 5 hours and the mixture was filtered and concentrated in vacuo. After the crude product was dissolved in $25 \mathrm{~mL}$ of $\mathrm{MeOH}$ at room temperature was added $\mathrm{NaCNBH}_{4}(0.96 \mathrm{~g}, 15.3 \mathrm{mmol})$. The mixture was stirred for overnight and then quenched with water. The organic layer was separated and the aqueous layer was extracted with $\mathrm{CH}_{2} \mathrm{Cl}_{2}$. The combined organic extracts were washed with brine, dried over anhydrous $\mathrm{MgSO}_{4}$, filtered, and concentrated in vacuo. Purification by silica gel flash chromatography (EtOAc/ $n$-Hexane, $33: 66)$ gave $1.93 \mathrm{~g}(59 \%)$ of the product (6LL) as colorless oil. ${ }^{1} \mathrm{H}$ NMR $\left(300 \mathrm{MHz}, \mathrm{CDCl}_{3}\right) \delta 7.65(\mathrm{~d}, 1 \mathrm{H}), 7.39-7.26(\mathrm{~m}, 5 \mathrm{H})$, 4.64 (q, 1H), 3.74 (s, 3H), 3.24 (q, 1H), 2.79 (broad d, 2H), $2.51(\mathrm{q}, 1 \mathrm{H}), 1.78-58(\mathrm{~m}, 6 \mathrm{H}), 1.45-1.43(\mathrm{~m}, 4 \mathrm{H}), 1.31(\mathrm{~m}, 1 \mathrm{H})$, 1.01-0.91 (m, 12H). All other three, 6LI, 6II and 6IL, were prepared in the same manner as for $6 \mathbf{L L}$.

Preparation of 7. To the solution of compound 6LL ( $1.93 \mathrm{~g}$, $4.62 \mathrm{mmol})$ in $100 \mathrm{~mL}$ of THF with cooling at $-10{ }^{\circ} \mathrm{C}$ and was added $\mathrm{NaH}$ (1.1 g, $27.7 \mathrm{mmol})$. The mixture was stirred for 1 hour at $-10{ }^{\circ} \mathrm{C}$ and then was added triphosgene $(1.5 \mathrm{~g}, 5.08$ $\mathrm{mmol}$ ) in $20 \mathrm{~mL}$ of THF with cooling at $-10^{\circ} \mathrm{C}$. The mixture was stirred for 2 hours at $-10^{\circ} \mathrm{C}$, and then quenched with $\mathrm{H}_{2} \mathrm{O}$. The organic layer was separated and the aqueous layer was extracted with $\mathrm{CH}_{2} \mathrm{Cl}_{2}(10 \mathrm{~mL} \times 5)$. The combined organic extracts were washed with brine, dried over anhydrous $\mathrm{MgSO}_{4}$, filtered, and concentrated in vacuo. Purification by silica gel flash chromatography (EtOAc/n-Hexane, 20:80) gave $1.86 \mathrm{~g}$ $(84.5 \%)$ of the product (7LL) as a colorless oil. ${ }^{1} \mathrm{H}$ NMR (300 $\left.\mathrm{MHz}, \mathrm{CDCl}_{3}\right) \delta$ 7.38-7.28 (m, 5H), $6.55(\mathrm{~d}, 1 \mathrm{H}), 5.24(\mathrm{q}, 1 \mathrm{H})$, $4.56(\mathrm{~m}, 1 \mathrm{H}), 4.44(\mathrm{~m}, 1 \mathrm{H}), 3.75(\mathrm{~s}, 3 \mathrm{H}), 3.49-3.38(\mathrm{~m}, 5 \mathrm{H})$, 1.69-1.64 (m, 10H), 1.00-0.93 (m, 12H). All other three, 7LI, 7II and 7IL, were prepared in the same manner as for 7LL.

Preparation of 8. To the solution of compound 7LL ( $1.86 \mathrm{~g}$, $3.87 \mathrm{mmol}$ ) in $50 \mathrm{~mL}$ of hexane at room temperature, was added $\mathrm{MsOH}(1.25 \mathrm{~mL}, 19.4 \mathrm{mmol})$ and anisole $(1.05 \mathrm{~mL}, 9.67$ $\mathrm{mmol})$. The mixture was refluxed for 4 hours, cooled and then quenched with $1 \mathrm{~mL}$ of saturated $\mathrm{NaHCO}_{3}$ solution. The organic layer was separated and the aqueous layer was extracted with $\mathrm{CH}_{2} \mathrm{Cl}_{2}$. The combined organic extracts were dried over anhydrous $\mathrm{MgSO}_{4}$, filtered, and concentrated in vacuo. Purification by silica gel flash chromatography $\left(\mathrm{CH}_{2} \mathrm{Cl}_{2} / \mathrm{MeOH}, 10: 1\right)$ gave debenzylated product $1.0 \mathrm{~g}(69 \%)$. To the solution of debenzylated product $(1.0 \mathrm{~g}, 2.66 \mathrm{mmol})$ in $10 \mathrm{~mL}$ of DMF was added $\mathrm{NaN}_{3}(0.34 \mathrm{~g}, 5.3 \mathrm{mmol})$. The mixture was stirred for overnight at $80^{\circ} \mathrm{C}$. The mixture was cooled, organic layer was separated and the aqueous layer was extracted with EtOAc. The combined organic extracts were washed with brine (10 $\mathrm{mL} \times 3$ ) dried over anhydrous $\mathrm{MgSO}_{4}$, filtered, and concentrat- ed in vacuo. Purification by silica gel flash chromatography $\left(\mathrm{CH}_{2} \mathrm{Cl}_{2} / \mathrm{MeOH}, 10: 1\right)$ gave $0.4 \mathrm{~g}(40 \%)$ of the product $8 \mathbf{L L}$. ${ }^{1} \mathrm{HNMR}\left(300 \mathrm{MHz}, \mathrm{CDCl}_{3}\right) \delta 6.65(\mathrm{~d}, 1 \mathrm{H}), 5.08$ (broad s, $\left.1 \mathrm{H}\right)$, $4.50(\mathrm{~m}, 1 \mathrm{H}), 4.40(\mathrm{t}, 1 \mathrm{H}), 3.74(\mathrm{~m}, 1 \mathrm{H}), 3.72(\mathrm{~s}, 3 \mathrm{H}), 3.65(\mathrm{t}, 1 \mathrm{H})$, $3.43-3.38(\mathrm{~m}, 2 \mathrm{H}), 3.21(\mathrm{~m}, 1 \mathrm{H}), 1.68-1.56(\mathrm{~m}, 6 \mathrm{H}), 0.99-0.91$ $(\mathrm{m}, 12 \mathrm{H})$. All other three, 8LI, 8II and $\mathbf{8 I L}$, were prepared in the same manner as for $8 \mathbf{L L}$.

Preparation of 9. To the solution of compound $8 \mathbf{L L}(300 \mathrm{mg}$, $0.78 \mathrm{mmol})$ in $20 \mathrm{~mL}$ of $\mathrm{MeOH}$ was added $\mathrm{Pd} / \mathrm{C}(0.1 \mathrm{~g})$ and the resulting solution was stirred for overnight under atmospheric pressure of $\mathrm{H}_{2}$ at room temperature. The solution was filtered and concentrated in vacuo to yield crude product 9LL. All other three, 9LI, 9II and 9IL, were prepared in the same manner as for 9LL. ${ }^{1} \mathrm{H}$ NMR (300 MHz, $\left.\mathrm{CDCl}_{3}\right) \delta 6.77(\mathrm{~d}, 1 \mathrm{H}), 5.22$ (broad $\mathrm{s}, 1 \mathrm{H}), 4.57-4.51(\mathrm{~m}, 1 \mathrm{H}), 4.38(\mathrm{q} 1 \mathrm{H}), 3.72(\mathrm{~s}, 3 \mathrm{H}), 3.72-3.65$ $(\mathrm{m}, 1 \mathrm{H}), 3.57(\mathrm{t}, 1 \mathrm{H}), 3.17(\mathrm{q}, 1 \mathrm{H}), 2.88-2.72(\mathrm{~m}, 2 \mathrm{H}), 1.68-1.56$ $(\mathrm{m}, 6 \mathrm{H}), 0.92(\mathrm{~m}, 12 \mathrm{H})$.

Preparation of 10. To the solution of compound 9LL (25 mg, $0.07 \mathrm{mmol})$ in $3 \mathrm{~mL}$ of THF was added phenyl isocyanate (7.6 $\mu \mathrm{L}, 0.07 \mathrm{mmol})$. The mixture was stirred for 3 hours at room temperature. The solution was concentrated in vacuo to yield crude product. Purification by silica gel flash chromatography (EtOAc/n-Hexane, 2:1) gave $20 \mathrm{mg}$ of the product 10LL; ${ }^{1} \mathrm{H}$ NMR (300 MHz, $\left.\mathrm{CDCl}_{3}\right) \delta 7.69(\mathrm{~s}, 1 \mathrm{H}), 7.39$ (d, 2H, ArH), 7.25 (t, 2H, ArH), 6.99 (t, 1H, ArH), 5.95 (broad s, 1H), 5.78 (broad s, 1H), $4.51(\mathrm{~m}, 1 \mathrm{H}), 4.28(\mathrm{q} 1 \mathrm{H}), 3.87(\mathrm{~m}, 1 \mathrm{H}), 3.71(\mathrm{~s}$, $3 \mathrm{H}), 3.70-3.61(\mathrm{~m}, 2 \mathrm{H}), 3.26(\mathrm{~m}, 2 \mathrm{H}), 1.74-1.50(\mathrm{~m}, 6 \mathrm{H}), 0.86$ (m, 12H). FAB Mass: $m / z 476(\mathrm{M}++1)$. 10LI; ${ }^{1} \mathrm{H}$ NMR $(300$ $\left.\mathrm{MHz}, \mathrm{CDCl}_{3}\right) \delta 7.35(\mathrm{~d}, 2 \mathrm{H}, \mathrm{ArH}), 7.25(\mathrm{t}, 2 \mathrm{H}, \mathrm{ArH}), 6.99(\mathrm{t}$, $1 \mathrm{H}, \mathrm{ArH}), 4.49(\mathrm{q}, 1 \mathrm{H}), 4.29(\mathrm{q}, 1 \mathrm{H}), 3.87(\mathrm{~m}, 1 \mathrm{H}), 3.71(\mathrm{~s}, 3 \mathrm{H})$, $3.70-3.63(\mathrm{~m}, 2 \mathrm{H}), 3.28(\mathrm{~m}, 2 \mathrm{H}), 1.87(\mathrm{~m}, 1 \mathrm{H}), 1.67(\mathrm{~m}, 1 \mathrm{H})$, $1.55(\mathrm{~m}, 1 \mathrm{H}), 1.37(\mathrm{~m}, 1 \mathrm{H}), 1.16(\mathrm{~m}, 1 \mathrm{H}), 0.95(\mathrm{~m}, 1 \mathrm{H}), 0.86$ (m, 12H). FAB Mass: $m / z 476(\mathrm{M}++1)$. 10II; ${ }^{1} \mathrm{H}$ NMR $(300$ $\left.\mathrm{MHz}, \mathrm{CDCl}_{3}\right) \delta 7.65($ broad s, $1 \mathrm{H}), 7.39$ (d, 2H, ArH), $7.24(\mathrm{t}$, 2H, ArH), 7.07 (d, 1H), 6.99 (t, 1H, ArH), 5.87 (broad s, 1H), 5.59 (broad s, 1H), $4.47(\mathrm{q}, 1 \mathrm{H}), 4.16(\mathrm{~m}, 1 \mathrm{H}), 3.81-3.65(\mathrm{~m}$, $2 \mathrm{H}), 3.73(\mathrm{~s}, 3 \mathrm{H}), 3.23(\mathrm{~m}, 2 \mathrm{H}), 2.10(\mathrm{~m}, 1 \mathrm{H}), 1.87(\mathrm{~m}, 1 \mathrm{H})$, $1.47-1.43(\mathrm{~m}, 3 \mathrm{H}), 1.15(\mathrm{~m}, 1 \mathrm{H}), 0.86(\mathrm{~m}, 12 \mathrm{H})$. FAB Mass: $\mathrm{m} / \mathrm{z}$ $476(\mathrm{M}++1)$. 10IL; ${ }^{1} \mathrm{H}$ NMR $\left(300 \mathrm{MHz}, \mathrm{CDCl}_{3}\right) \delta 7.55$ (broad $\mathrm{s}, 1 \mathrm{H}), 7.38$ (d, 2H, ArH), 7.24 (t, 2H, ArH), 7.04 (d, 1H), 7.00 (t, 1H, ArH), 5.85 (broad s, 1H), 4.50-4.44 (m, 1H), 3.90-3.85 $(\mathrm{m}, 1 \mathrm{H}), 3.77-3.64(\mathrm{~m}, 2 \mathrm{H}), 3.74(\mathrm{~s}, 3 \mathrm{H}), 3.45(\mathrm{~m}, 1 \mathrm{H}), 3.28-3.19$ (m, 2H), $2.17(\mathrm{~m}, 1 \mathrm{H}), 1.60-1.43(\mathrm{~m}, 5 \mathrm{H}), 0.92-0.79(\mathrm{~m}, 12 \mathrm{H})$. FAB Mass: $m / z 476(\mathrm{M}++1)$.

Preparation of 11. To the solution of compound 10LL (23 $\mathrm{mg}, 0.064 \mathrm{mmol}$ ) in $2 \mathrm{~mL}$ of $\mathrm{CH}_{3} \mathrm{CN}$ was added phenyl pyrimidin-2-yl-carbamate $(20 \mathrm{mg}, 0.13 \mathrm{mmol}$ ). The mixture was refluxed for $3 \mathrm{~h}$. The solution was concentrated in vacuo to yield crude product. Purification by silica gel flash chromatography $\left(\mathrm{CH}_{2} \mathrm{Cl}_{2} / \mathrm{MeOH}, 50: 1\right)$ gave $20 \mathrm{mg}$ of the product (11LL). 11LL; ${ }^{1} \mathrm{H} \mathrm{NMR}\left(300 \mathrm{MHz}, \mathrm{CDCl}_{3}\right) \delta 9.40(\mathrm{~s}, 1 \mathrm{H}), 8.53(\mathrm{~d}, 2 \mathrm{H}), 6.93$ $(\mathrm{t}, 1 \mathrm{H}), 6.79(\mathrm{~d}, 1 \mathrm{H}), 5.36($ broad s, $2 \mathrm{H}), 4.57-4.49(\mathrm{~m}, 1 \mathrm{H})$, $4.39(\mathrm{t} 1 \mathrm{H}), 3.95(\mathrm{~m}, 1 \mathrm{H}), 3.72(\mathrm{~s}, 3 \mathrm{H}), 3.62(\mathrm{t}, 1 \mathrm{H}), 3.48(\mathrm{~m}$, $2 \mathrm{H}), 3.22(\mathrm{q}, 1 \mathrm{H}), 1.63-1.55(\mathrm{~m}, 6 \mathrm{H}), 0.90-0.79(\mathrm{~m}, 12 \mathrm{H})$. FAB Mass: $m / z 478\left(\mathrm{M}^{+}+1\right)$. 11LI; ${ }^{1} \mathrm{H}$ NMR $\left(300 \mathrm{MHz}, \mathrm{CDCl}_{3}\right) \delta$ $9.39(\mathrm{~s}, 1 \mathrm{H}), 8.55(\mathrm{~d}, 2 \mathrm{H}), 6.93(\mathrm{t}, 1 \mathrm{H}), 6.74(\mathrm{~d}, 1 \mathrm{H}), 5.41$ (broad $\mathrm{s}, 1 \mathrm{H}), 5.19$ (broad s, 1H), 4.54-4.49 (m, 1H), $4.40(\mathrm{t}, 1 \mathrm{H}), 3.99$ $(\mathrm{m}, 1 \mathrm{H}), 3.72(\mathrm{~s}, 3 \mathrm{H}), 3.59(\mathrm{t}, 1 \mathrm{H}), 3.47(\mathrm{~m}, 2 \mathrm{H}), 3.22(\mathrm{q}, 1 \mathrm{H})$, 
$1.88(\mathrm{~m}, 1 \mathrm{H}), 1.63(\mathrm{~m}, 2 \mathrm{H}), 1.55-1.14(\mathrm{~m}, 3 \mathrm{H}), 0.88-0.79(\mathrm{~m}$, 12H). FAB Mass: $m / z 478\left(\mathrm{M}^{+}+1\right)$. 11II; ${ }^{1} \mathrm{H}$ NMR $(600 \mathrm{MHz}$, $\left.\mathrm{CDCl}_{3}\right) \delta 9.42(\mathrm{~s}, 1 \mathrm{H}), 8.52(\mathrm{~d}, 2 \mathrm{H}), 6.91(\mathrm{t}, 1 \mathrm{H}), 6.60(\mathrm{~d}, 1 \mathrm{H})$, 5.41 (broad s, 2H), $4.51(\mathrm{~m}, 1 \mathrm{H}), 3.97(\mathrm{~m}, 2 \mathrm{H}), 3.75(\mathrm{t}, 1 \mathrm{H})$, $3.71(\mathrm{~s}, 3 \mathrm{H}), 3.49-3.46(\mathrm{~m}, 2 \mathrm{H}), 3.20(\mathrm{q}, 1 \mathrm{H}), 2.04-1.84(\mathrm{~m}, 2 \mathrm{H})$, $1.40(\mathrm{~m}, 2 \mathrm{H}), 1.14(\mathrm{~m}, 2 \mathrm{H}), 0.89-0.77(\mathrm{~m}, 12 \mathrm{H})$. FAB Mass: $m / z 478\left(\mathrm{M}^{+}+1\right)$; 11IL; ${ }^{1} \mathrm{H}$ NMR $\left(600 \mathrm{MHz}, \mathrm{CDCl}_{3}\right) \delta 9.43$ (broad s, 1H), $8.53(\mathrm{~d}, 2 \mathrm{H}), 6.91(\mathrm{t}, 1 \mathrm{H}), 6.61(\mathrm{~d}, 1 \mathrm{H}), 5.41$ (broad s, 2H), $4.52(\mathrm{~m}, 1 \mathrm{H}), 3.98(\mathrm{~m}, 2 \mathrm{H}), 3.78(\mathrm{t}, 1 \mathrm{H}), 3.71(\mathrm{~s}$, $3 \mathrm{H}), 3.51-3.44(\mathrm{~m}, 2 \mathrm{H}), 3.22(\mathrm{q}, 1 \mathrm{H}), 2.04-2.00(\mathrm{~m}, 1 \mathrm{H}), 1.66-$ $1.58(\mathrm{~m}, 2 \mathrm{H}), 1.53(\mathrm{~m}, 1 \mathrm{H}), 1.39(\mathrm{~m}, 1 \mathrm{H}), 1.16(\mathrm{~m}, 1 \mathrm{H}), 0.99$ $0.77(\mathrm{~m}, 12 \mathrm{H})$. FAB Mass: $m / z 478\left(\mathrm{M}^{+}+1\right)$.

Preparation of 12. To the solution of compound 11LL (14 $\mathrm{mg}, 0.04 \mathrm{mmol})$ in $2 \mathrm{~mL}$ of THF was added benzene sulfonyl chloride $(6 \mu \mathrm{L}, 0.05 \mathrm{mmol})$ and TEA $(3 \mu \mathrm{L})$. The mixture was refluxed for 1 hour. The solution was concentrated in vacuo to yield crude product. Purification by silica gel flash chromatography $\left(\mathrm{CH}_{2} \mathrm{Cl}_{2} / \mathrm{MeOH}, 10: 1\right)$ gave $9 \mathrm{mg}$ of the product $12 \mathrm{LL}$; ${ }^{\mathrm{l}} \mathrm{H}$ NMR $\left(300 \mathrm{MHz}, \mathrm{CDCl}_{3}\right) \delta 7.87(\mathrm{~d}, 2 \mathrm{H}, \mathrm{ArH}), 7.53(\mathrm{t}, 3 \mathrm{H}$, ArH), $6.82(\mathrm{~m}, 1 \mathrm{H}), 5.96(\mathrm{~m}, 1 \mathrm{H}), 5.45($ broad s, $1 \mathrm{H}), 4.47(\mathrm{~m}$, $1 \mathrm{H}), 4.11-3.72(\mathrm{~m}, 3 \mathrm{H}), 3.72(\mathrm{~s}, 3 \mathrm{H}), 3.22(\mathrm{~m}, 1 \mathrm{H}), 2.96(\mathrm{~m}, 2 \mathrm{H})$, 2.05-1.80 (m, 2H), 1.73-1.30 (m, 4H), 0.93-0.87 (m, 12H). FAB Mass: $m / z 497\left(\mathrm{M}^{+}+1\right)$. 12LI; ${ }^{1} \mathrm{H}$ NMR $\left(300 \mathrm{MHz}, \mathrm{CDCl}_{3}\right) \delta$ $7.86(\mathrm{~d}, 2 \mathrm{H}, \mathrm{ArH}), 7.55$ (t, 3H, ArH), 6.78 (d, 1H), 5.74 (broad $\mathrm{s}, 1 \mathrm{H}), 4.49(\mathrm{q}, 1 \mathrm{H}), 4.36(\mathrm{t}, 1 \mathrm{H}), 3.83(\mathrm{~m}, 1 \mathrm{H}), 3.73(\mathrm{~s}, 3 \mathrm{H})$, $3.72-3.71(\mathrm{~m}, 1 \mathrm{H}), 3.21(\mathrm{q}, 1 \mathrm{H}), 3.04-2.98(\mathrm{~m}, 2 \mathrm{H}), 1.88(\mathrm{~m}$, $1 \mathrm{H}), 1.67-1.52(\mathrm{~m}, 3 \mathrm{H}), 1.38(\mathrm{~m}, 1 \mathrm{H}), 1.19(\mathrm{~m}, 1 \mathrm{H}), 0.95-0.86$ (m, 12H). FAB Mass: $m / z 497\left(\mathrm{M}^{+}+1\right)$. 12II; ${ }^{1} \mathrm{H}$ NMR $(300$ $\left.\mathrm{MHz}, \mathrm{CDCl}_{3}\right) \delta 7.85(\mathrm{~d}, 2 \mathrm{H}, \mathrm{ArH}), 7.55(\mathrm{t}, 3 \mathrm{H}, \mathrm{ArH}), 6.82(\mathrm{~d}$, $1 \mathrm{H}), 6.11(\mathrm{~m}, 1 \mathrm{H}), 5.50($ broad s, $1 \mathrm{H}), 4.49(\mathrm{~m}, 1 \mathrm{H}), 3.91(\mathrm{~d}, 1 \mathrm{H})$, 3.80-3.60 (m, 2H), $3.72(\mathrm{~s}, 3 \mathrm{H}), 3.22-2.95(\mathrm{~m}, 3 \mathrm{H}), 2.11-1.75$ $(\mathrm{m}, 3 \mathrm{H}), 1.55-1.24(\mathrm{~m}, 3 \mathrm{H}), 0.92-0.85(\mathrm{~m}, 12 \mathrm{H})$. FAB Mass: $m / z 497\left(\mathrm{M}^{+}+1\right) .12 \mathrm{IL} ;{ }^{1} \mathrm{H}$ NMR $\left(300 \mathrm{MHz}, \mathrm{CDCl}_{3}\right) \delta 7.83(\mathrm{~d}$, 2H, ArH), 7.54 (t, 3H, ArH), $6.77(\mathrm{~d}, 1 \mathrm{H}), 5.98(\mathrm{~m}, 1 \mathrm{H}), 5.66$ (broad s, 1H), $4.51(\mathrm{~m}, 1 \mathrm{H}), 3.90(\mathrm{~m}, 1 \mathrm{H}), 3.81-3.68(\mathrm{~m}, 2 \mathrm{H})$, $3.73-3.70(\mathrm{~m}, 1 \mathrm{H}), 3.72(\mathrm{~s}, 3 \mathrm{H}), 3.22(\mathrm{q}, 1 \mathrm{H}), 3.20-3.09(\mathrm{~m}, 2 \mathrm{H})$, $2.10(\mathrm{~m}, 1 \mathrm{H}), 2.01-1.77(\mathrm{~m}, 2 \mathrm{H}), 1.44-1.13(\mathrm{~m}, 3 \mathrm{H}), 0.93-0.81$ (m, 12H). FAB Mass: $m / z 497\left(\mathrm{M}^{+}+1\right)$.

Preparation of 1, 2 and 3. To the solution of the compound 10LL ( $20 \mathrm{mg}, 0.04 \mathrm{mmol}$ ) in $3 \mathrm{~mL}$ of $\mathrm{MeOH}$ was added $1 \mathrm{~N}$ $\mathrm{NaOH}$. The mixture was stirred for 1 hour at room temperature. The solution was concentrated in vacuo to yield crude product. Purification by silica gel flash chromatography $\left(\mathrm{CH}_{2} \mathrm{Cl}_{2} / \mathrm{MeOH}\right.$,
10:1) gave $4 \mathrm{mg}$ of the target compound $\mathbf{1 L L}$. The purity was checked by HPLC and the compound was identified by Mass. All other compounds were prepared in the same manner as for 1LL. 1LL, 1LI, 1II, and 1IL: FAB Mass: $m / z 462\left(\mathrm{M}^{+}+1\right)$. Compounds 2 and $\mathbf{3}$ were prepared in the same manner as for compound 1. 2LL, 2LI, 2II, and 2IL: FAB Mass: $m / z 464\left(\mathrm{M}^{+}+1\right)$. 3LL, 3LI, 3II, and 3IL: FAB Mass: $m / z 483\left(\mathrm{M}^{+}+1\right)$.

Acknowledgments. We thank the Gyeonggi Regional Research Center (GRRC) program of Gyeonggi province (2009B01), the HUFS Research Fund (2009) for financial support, and BK21 Program from MEST. WKL acknowledges the financial support from [KRF-2008-C00481 and NRF-20090081956].

\section{References}

1. For a review, see: Hurdle, J. G.; O’Neill, A. J.; Chopra, I. Antimicrob. Agents Chemother. 2005, 49, 4821.

2. (a) Fuller, A. T.; Mellows, G.; Woolford, M.; Banks, G. T.; Barrow, K. D.; Chain, E. B. Nature 1971, 234, 416. (b) Hughes, J.; Mellows, G. Biochem. J. 1978, 176, 305. (c) Casewell, M. W.; Hill, R. L. R. J. Antimicrob. Chemother. 1985, 15, 523.

3. Yanagisawa, T.; Lee, J. T.; Wu, H. C.; Kawakami. M. J. Biol. Chem. 1994, 269, 24304.

4. (a) Hurdle, J. G.; O’Neill, A. J.; Ingham, E.; Fishwick, C.; Chopra. I. Antimicrob. Agents Chemother. 2004, 48, 4366. (b) Nakama, T.; Nureki, O; Yokoyama, S. J. Biol. Chem. 2001, 276, 47387.

5. Bharatham, N.; Bharatham, K.; Lee, Y.; Kim, S.; Lazar, P.; Baek, A.; Park, C.; Lee, K. W.; Eum, H.; Ha, H.-J.; Yun, S. Y.; Lee, W.-K.; Kim, S.; Lee, K. W. Bull. Kor. Chem. Soc. 2010, 31, 606.

6. Lee, W. K.; Ha, H.-J. Aldrichimica Acta 2003, 36, 57.

7. Park, C. S.; Kim, M. S.; Sin, T. B.; Pyun, D. K.; Lee, C. H.; Choi, D.; Lee, W. K.; Chang, J.-W.; Ha, H.-J. J. Org. Chem. 2003, 68, 43.

8. (a) Chang, J.-W.; Ha, H.-J.; Park, C. S.; Kim, M. S.; Lee, W. K. Heterocycles 2002, 57, 1143. (b) Sin, T. B.; Kang, S. H.; Lee, K. S.; Lee, W. K.; Yun, H.; Dong, Y.; Ha, H.-J. J. Org. Chem. 2003, 68, 104.

9. (a) Satchell, D. P. N.; Satchell, R. S. Chem. Soc. Rev. 1975, 4, 231. (b) Denisko, O. V. In Comprehensive Organic Functional Group Transformation; Katritzky, A. R., Taylor, R. J. K., Eds.; Pergamon: Oxford, 2005; Vol. 6, pp 453. (c) Heinisch, G.; Matuszczak, B.; Purstinger, G.; Rakowitz, D. J. Heterocycl. Chem. 1995, 32, 13.

10. Mallakpour, S.; Rafiee, Z Synth. Comm. 2007, 37, 1927.

11. Pope, A. J.; Moore, K. J.; McVey, M.; Mensah, L.; Benson, N.; Osbourne, N.; Broom, N.; Brown, M. J. B.; O'Hanlon, P. J. J. Biol. Chem. 1998, 273, 31691. 